\title{
THE PERCEPTIONS OF PRACTITIONERS OF A CHILDREN DAY CARE CENTRE ABOUT AUTHORITY OF A SOCIAL WORKER
}

\author{
Lina Grudulaitė \\ Mykolas Romeris University
}

\begin{abstract}
The article seeks to reveal the importance of critical evaluation of authority of social workers. The problem of authority and different meanings attached to the role of a social worker are discussed and the practical and theoretical value of the research study is revealed. The article presents the theoretical explanations of the concept of authority and its ethical implications for social work practice at a children day care center. It also discusses the empirical findings of the qualitative case study conducted at the day care center X. The perceptions of its practitioners, what authority of a social worker means and consists of and how to gain it, are peresented. The article includes a detailed description of the specific context of the case study and indicates the selected research methods. The degree of reliability and validity of research study are also discussed. The empirical data of the case study is analyzed and discussed and conclusions are presented.
\end{abstract}

KEYWORDS: authority, social worker, ethics, children day care centers, case study.

\begin{abstract}
Anotacija
Straipsnyje atskleidžiama socialinių darbuotojų autoriteto kritiško vertinimo svarba, aptariama autoriteto problema ir skirtingos socialinio darbuotojo vaidmeniui priskiriamos reikšmès, taip pat mokslinio tyrimo apie socialinio darbuotojo autoritetą praktinè ir teorinè verté, pristatomi teoriniai autoriteto sąvokos paaiškinimai, aptariama galima etinè autoriteto įtaka socialinio darbo praktikai vaikų dienos centruose. Straipsnyje aptariami empiriniai vaikų dienos centro $\mathrm{X}$ atvejo kokybinio tyrimo duomenys, pristatoma, kaip vaikų dienos centro praktikai supranta socialinio darbuotojo autoritetą ir būdus, kaip tapti autoritetu. Pateikiamas detalus atvejo konteksto aprašymas ir pristatomi tyrimo metodai, aptariamas tyrimo rezultatų patikimumas ir pagrịstumas. Empiriniai duomenys analizuojami ir pristatomos tyrimo išvados.

PAGRINDINIAI ŽODŽIAI: autoritetas, socialinis darbuotojas, etika, vaikų dienos centras, atvejo analizè.
\end{abstract}

DOI: http://dx.doi.org/10.15181/tbb.v73i1.1275

\section{Introduction}

E. Gambrill (2001) argues that social work is an authority based profession. Different meanings attached to authority of a social worker might influence how social workers understand the concept and how they use their professional and personal authority in their daily practice. Eventhough the role of a social worker at a children day care center might overlap with a role of an educator; it also has some distinct and unique functions and values assigned only to this contemporary profession. A day care center for children is a structure with its own rules and boundaries (Sipovič, 2007). Despite of the importance and relevance of the topic 
to daily practice, there is a lack of research studies conducted to explore authority of a social worker working at the contemporary context of a day care center for children. Furthermore, there is a significant lack of research studies exploring authority of a social worker in general. According to O. Tijūnèliene (2006), the problem of authority is a practical and scientific problem and requires scientific recommendations, how to strengthen authority in contemporary conditions. The phenomena of authority of a teacher or parents has been analyzed and discussed by various researchers. The studies in the areas of education and psychology offer valuable insights about the phenomena of authority. Many explored research studies are based on the philosophical notions of authority and the relationalism perspective, which defines authority primarily not as a capacity but as a relationship (Bochenski, 2004). Despite of observed similarities in social theories describing the concept of authority, it remains a complex concept and has many interpretations and is influenced by social, cultural, political conditions of the time (Tijūnèlienè, 2006). The awareness about the professional authority or the lack of it might influence if social workers practice ethically and effectively. Therefore, authority is not only scientific, but also a practical problem in social work and deeper analysis is required to understand, how authority of a social worker is perceived by practitioners working at children day care centers to be able to improve social work practice.

The conducted research study is a qualitative participatory case study. It explores the phenomena of authority of a social worker in the contemporary context of a children day care center. The case study is bound by contemporary time and context and is aimed to answer the question, how the authority of a social worker is perceived by practitioners working at the children day care center X. The research participants were actively involved answering the question. It is a theoretical and empirical case study specific to time and space focusing on the phenomenon of authority of a social worker. The empical data of a case study was compared with the theoretical concepts of authority. The describtion of the case, reflections about the ethics of the research, bias and values, validation of the accuracy of findings, interpretations and agendas for change were included in the analysis of the findings of the research study.

\section{The Meanings of the Concept of Authority in Social Research}

The Oxford dictionary (2014) defines authority as "the power to give orders, make decisions, and influence others and confidence resulting from personal expertise". R. R. Robertson (2014, p. 23) also presents the perspective of instructional communication researchers of authority, who describe authority as "the effective use of power, in the form of influence and control". B. Bitinas (2004) does 
not support the definition of authority linked to power and argues that authority is linked firstly to being an example for others. Various research studies in the fields of education, psychology are based on premises of a relationalism perspective presented by J. M. Bochenski (2004). The philosopher emphasizes not just a capacity of individuals but puts a strong emphasis on the status of an individual, which derives from a relationship. According to J. M. Bochenski (2004), the authority figure might have certain features or capacities, which support their authority, but the main feature of authority is a relationship. It is argued that authority figure should be recognized to be authority and deliver an important message to other person. 2 main categories of authority are presented - epistemic and deontic authority. The first depends on professional training, skills and knowledge gained by specific social work training and the skills, which are used in daily professional practice. The second category is linked to power, which a concrete person has to give orders to others, make decisions. The philosopher argues that the most common form of abuse of deontic authority, when a person tries to get epistemic authority by force.

Recognition is also the essential feature of authority (Tijunèlienè, 2006). The researcher argues that authority informs the subject about something. O. Tijūnèlienè (2006) argues that "authority is gained by people, who speak courageously and clearly, who can say their opinion first, who without doubt declare their views, solve problems. They gain authority with their spirit, creative and moral energy. They orientate first, offer solutions and are not scared to risk. They know, when to speak and when to be silent. Society choose such people as their leaders and reject those in doubt, who cannot orientate in time, afraid of risk and unable to sacrifice" (2006, p. 145). Therefore, the researcher connects the phenomena of authority with the leadership and moral qualities of a person. It is argued that spiritual maturity is one of the most important elements for gaining authority and that a person with authority needs not only to be recognized but also to be trusted and represent moral ideals by the way they live and work to awake the desire of other to follow him / her and listen to. A. Skarbalienè, (2015) also explores close links between the concepts of authority and leadership. O. Tijūnèlienè (2006) argues that the qualities of a person only support their authority; however the main element of authority remains a relationship between authority and other person.

R. R. Robertson (2014) emphasizes the complexity and ambiguity of the concept. Nevertheless, he argues that there is a consensus among researchers that it exists in the relationships between people. He argues that understanding of the concept might depend on particular situations and people. Care, trust, respect are identified as relational communication elements for authority development. The researcher argues that once authority is earned, it needs to be maintained through evidence that it is reasonable and that power and influence are used properly. Au- 
thority can have ethical implications and become ethical problem if is not used properly by social work professionals. R. Hugman (2005) emphasizes the importance of professional ethics in social work, because the profession carries deontic authority and professionals exercise power in relation to service users. S. Banks (2006) claims that social work is based on contradictory aims and values, which are linked to care and control functions, what might sometimes create tensions between social workers and service users. C. Clark argues that "social work involves modelling ways of life and counselling over morally problematic issues" (2006, p. 75). Therefore, value neutrality is not possible or desirable among professionals of social work and the role requires demonstrating a virtuous character of a professional.

\section{The Description of the Case}

Children day care center are institutions, which offer social and educational services for children from social risk families. The first day care centers for children were opened in 1994. At the moment there are around 150 day care centers for children and $24 \%$ of children from social risk families are attending them. Communities in a partnership with municipalities establish day centers for children to spend their leisure time in a meaningful way and offer help with their homework. Day centers offer care for children during the day and additional services to fulfil the main needs of a child, which cannot be fulfilled by their families. At the same time social workers support parents to improve their parenting skills. Various preventive programs are offered to seek integration of kids from social risk families into schools, environment, society, protecting them from abuse, bullying and preventing from being taken to institutional care. Volunteering is well-developed at day care centers and social workers work alongside volunteers (Sipovič, 2007). 58 percent of practitioners at children day care centers are social workers (Sipovic, 2007). They often work alongside other practitioners such as psychologists and social pedagogues. According to legal requirements, unqualified worker cannot work at a day care center (Social Security and Labor Ministry, 2013). A role and authority of a social worker is confined by certain legal regulations and general requirements for a day center setting and the policies and values of the specific organization. The legal requirements set certain boundaries, expectations and powers for a role of a social worker and might impact, how social workers understand and use their professional and personal authority at work.

The perceptions on authority of a social worker were explored at the particular children day care center $\mathrm{X}$. The day care center is managed by the NGO ' $\mathrm{X}$ ' 
and is partly funded by the Ministry of Social Security and Labor and private funders. Currently, there are two permanent social workers responsible for organizing day care center activities. Currently, it is attended by 25 children from 7 to 14 years old from "social risk families", "families lacking social skills", experiencing difficulties or living on benefits. There are various routes, how children can come to the day care center X, some are referred by state social workers or social pedagogues from schools, others come because their parents hear about a day care center or their friends are attending it. There is a selection process and a waiting list to attend the day care center X. Therefore, families are attending interviews, fill questionnaires. The evidence is needed that family needs support for a child to attend the day care center X. The priority is given to children from the local area to increase cooperation with parents and to work with local community. Children and parents get services for free. The attendance is voluntary and children are not obliged to participate in all activities. Children come after school and get help with their homework, get snacks and attend various activities, which aim to develop their social and practical skills, increase their emotional awareness, coping skills. Social workers try to work not only with children, but also to cooperate with their families, school and other agencies. Qualified social workers work together with psychologists, social work practice students and volunteers. The NGO " $\mathrm{X}$ " is guided by Christian values and principles. However, not all workers or children are practicing faith, but all staff members are familiar with the values and principles of organization and adhere to them. The methodology of organization is an educative approach based on the recognition of the inherent value and dignity of every person, on his/her treatment as an integral person, on building a strong relationship and nurturing it through time and persistent work seeking his / her empowerment. When designing the activities, the attention is drawn to peculiar needs of a person. Workers and practitioners have daily reflections about their work and weekly team meetings and monthly supervisions. There are legal requirements and documents, which describe the role of a social worker working at the day care center X and describe rights, duties and powers of a social worker. Also, the authority of a social worker at a day care center might be formed by the values of organization and personal values of social workers working at the organization. Different meanings attached to the role of a social worker and different qualities of workers, might influence, how social workers understand and use their professional and personal authority in their daily practice at the day care center X and the aim of the research study was to explore the perceptions of various practitioners of a day care center about the authority of a social worker working at a day care center. 


\section{The Research Methods and validating the Accuracy of Findings}

A purposefully selected site, which could help to understand the research question more in depth, was chosen. The choice was based on good access to participants, documents and opportunity for a researcher to be actively engaged with participants of research - a convenient sample. A convenient sampling of research participants was also used because of a limited number of practitioners working at the research site. The case study protocol was developed, therefore it is possible to familiarize with all procedures, interview questions and replicate the study in other settings, what increases validity of the study. Archival analysis was conducted and data was collected from documents, which define the functions and the role of a social worker at the organization X, 2 small focus group discussions were organized with 7 practitioners of the day care center $\mathrm{X}$ about the phenomena of authority of a social worker and observational data of focus group discussions was also used for data analysis. Data was triangulated to increase validity of the study. The validity was increased by following instructions of guide books, how to carry effectively a document analysis, focus groups and interviews and how to analyze research data. The open-ended, emerging data was collected and coded and themes were developed and compared.

The conducted case study is context bound and perceptions were limited to practitioners connected to the specific day care center X and might reveal only the perceptions of practitioners of the specific organization. However, the case study allowed to explore the concept of authority of a social worker to produce deeper understanding, how the phenomena operates and what the concept might mean at the specific context and how to become a social worker with authority. Some validity of data might have been lost because of translation from Lithuanian to English by a researcher and the meaning of the words of participants might have been changed in the process. Grounded theory approach was chosen to analyze data, because the aim of the research project was to produce new theories grounded by research data. Useful concepts and key phrases were marked in the chunks of transcribed text and categorized to thematic groups. Coded categories were linked together in theoretical models around the central category of authority of a social worker. The constructed categories were compared with pre-existing theories if they match them or new theories were searched to explain them (Creswell, 2003). Observational data was used to complement verbal data.

\section{The Discussion of empirical Data}

All focus group participants, when asked to define, how they understand, what the concept of authority means, identified it as being hard to define and measure. 
The practitioner A stated that "it is hard to evaluate your own authority, because it can be revealed later" and "it is hard to understand, what it is". The practitioner B expanded the idea that often "we do not see and measure our influence, maybe in a long term people can reflect, what a relationship or being at the organization does for them and sometimes they express their gratitude, but most of the time, they leave a question mark if it was our contribution or their own towards their growth". Practitioner C simply expressed that "she never thinks if she is authority or not". Therefore, even though the concept of authority was familiar for all the practitioners participating in the focus groups, it was expressed by all participants that it is not usual to reflect and think about their own authority and it is difficult to discover if you are authority to service users, because service users rarely give feedback on that. The practitioner D stated that it might be hard to define your own authority, because "its influence might be beyond work boundaries and the results might come in 10 years or so". Therefore, the dimension of time was identified as being important to test if a person is authority to someone. The other difficulty, which was identified by practitioners A and B that it is hard to tell "what kind of authority you have". Practitioner A argued that it is difficult to know if "children listen to you because of fear or respect". The practitioners identified two main types of authority - "something you fear" or "forced institution" having influence you want it or not and "authority of love", "authority of respect". It was suggested that the ideal social worker would have a former authority. All practitioners needed time to define, what authority is and seemed a bit confused and thoughtful answering the question. Their silence and body language indicated that it was not an easy question for them and it was hard to find words to define the concept of authority.

The concepts of authority, which were presented by practitioners, were close to a relationalism perspective, which defines authority not as a capacity but as a relationship (Bochenski, 2004). "Respect", "fear", "love", "having influence" - the words, which were frequently used by practitioners define a relationship with their service users, but also describe the phenomena of authority. As R. Hugman (2005) participants also emphasized the importance of professional ethics in social work, because professionals exercise power in relation to their service users. It was also identified by one participant that "authority sometimes might conflict with a need of a person to have an equal relationship with other person". As S. Banks (2006) they presented contradictory aims and values of social work, which are linked to care and control functions of the role, what sometimes might create tensions and unclarity "if children respect you or fear sanctions" and power attached to your role. The new categories were introduced by practitioners, which were not pre- 
sented in the analyzed theories such as "authority of love" and "a social worker, who loves his job", which might be closer to the Christian definitions of authority or the concept of pedagogical love described in the research study of K. Määttä and S. Uusiautti (2012).

Eventhough the concept seemed familiar to all interviewed practitioners, it was not clear for most of them, what it actually means. However, when the question was made more specific and when the practitioners were asked, what it means to be a social worker with authority at a day care center, where they practice, practitioners began to share more confidently their insights about the concept. Despite of their initial difficulties practitioners identified several criterias, which might be useful measuring and evaluating authority of a social worker at a day care center. One of them can be "how much the child tells you, opens up and trusts you" identified by practitioner A. Other criteria might be "how you manage to lead a group" and "if they listen to you and you feel respected" added by practitioner B. Practitioner $\mathrm{C}$ argued that authority of a social worker at a day center is "your own feeling that you have certain competencies" and practitioner D also had a similar view that it is "a good feeling that you have certain understanding in the area". The perceptions of authority, which were identified by practitioners, can be divided into two different categories - one category, which defines authority as a relationship, primarily with a child as the main service user of a day care center. Other category is related to internal feelings of practitioners about them having certain qualities and competences, their self-confidence at work. The perception of a practitioner that he/she has understanding in the area and competencies were emphasized as important qualities for building authority of a social worker at a day care center. The categories are similar to J. M. Bochenski's (2004), who divides authority into epistemic or deontic authority. As focus group a participant indicated service users might do something out of respect and love or out fear and the line between these two types of authority is not always clear and easy to identify. The other dilemma identified by a practitioner C "that it is not always clear if you are authority or more a leader". Practitioner B also identified a quality "to lead a group" as a quality, which a social worker has to possess. The dilemma of leadership versus authority is explored in depth by A. Skarbalienè (2015), who also argues that there is a lot of in common between the concepts of authority and leadership. 


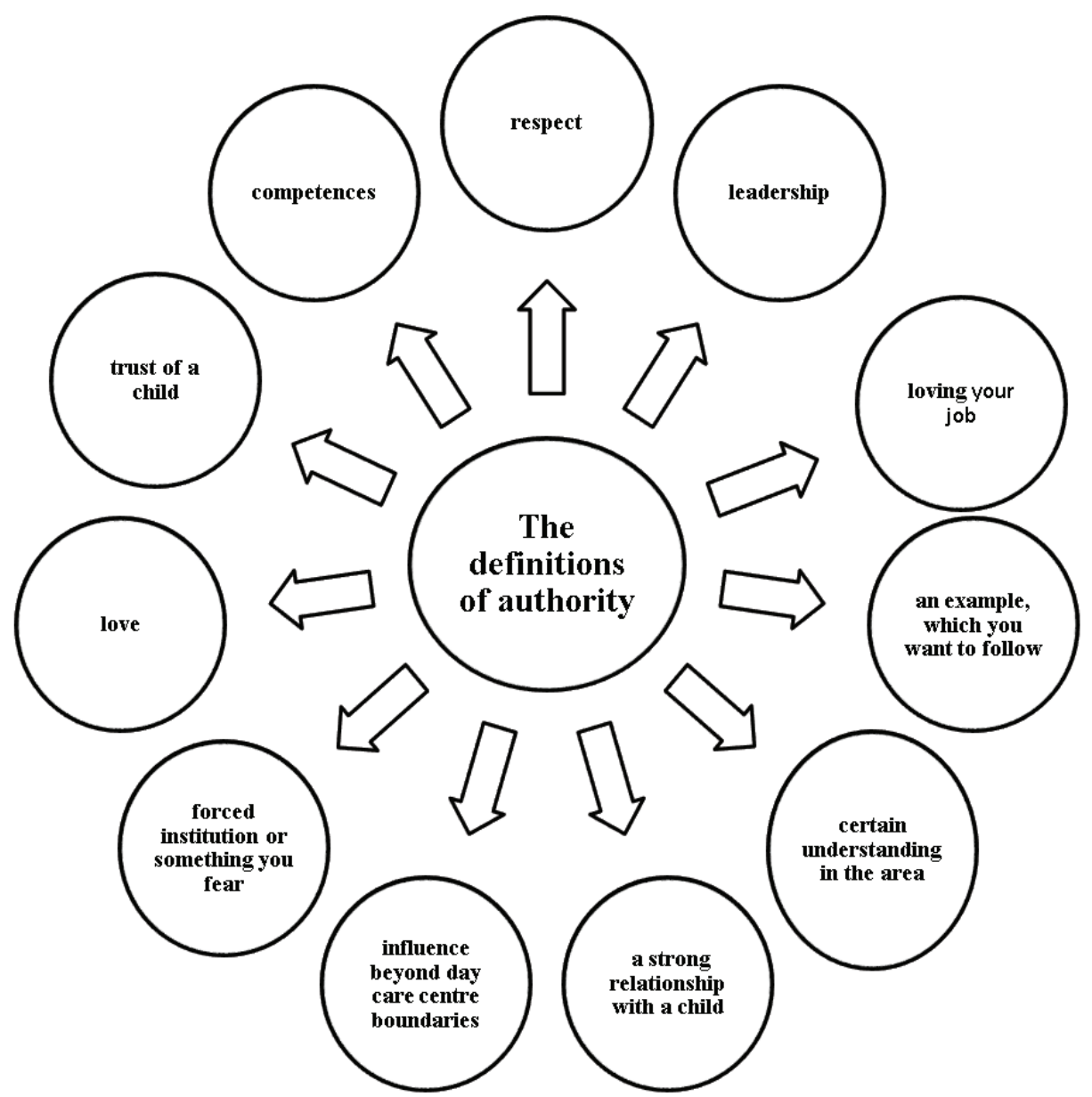

Fig. 1. Definitions of authority provided by focus group participants

\section{The Definitions of Authority provided by Focus Group Respondents}

The picture represents the sub-categories of "authority" constructed from the definitions provided by practitioners, who participated in the focus group. As it was discussed above, it is hard to find a unified definition of the concept as it encompasses various meanings attached to it by practitioners and reflects its complexity. Some are very general; others are more specific to a profession of a social worker at the children day care center. Most of them are also encountered in the reviewed scientific literature. However, some concepts are relatively unexplored and unique such as "authority of love", "a social worker, who loves his / her job", "influence beyond boundaries of a day care center" and might reflect the values of practitioners of the particular day care center and the values of the particular 
organization. Most of the concepts used by practitioners to describe authority are not instrumental and describe moral dimension- such as a relationship with a child, an approach of a child towards a social worker, which includes respect, trust, and love, willingness to follow him/her or a forced institution and something that they fear. Other definitions describe professional and personal qualities such as competencies, leadership, loving a job, certain understanding in the area as the essential components of authority concept. These characteristics are close to the concept of O.Tijūnèlienè (2000), who describes authority as the influence of a person in various aspects of the life of other person or a group and suggests the characteristics of a person, who have a strong influence for others and gained trust and respect. The values and moral dimension is also emphasized in the document of the day care center $\mathrm{X}$, which defines the vision, mission, objectives, tasks, methods of work of a specific day center at the organization $X$. It puts a lot of emphasis on a positive relationship with a child and states that workers need constantly to be educated and reflect on their practice in order to be able to educate others. This document is important, because it sets certain expectations about the value system of a social worker working at the specific organization and places a lot of attention on positive relationships as the means to get authority. These values were also reflected in the focus group discussion, where several practitioners emphasized the qualities related to maintaining strong relationships with service users and colleagues as the key elements of social worker's authority. These positive aspects of authority dominated in the responses. One of the reasons, why practitioners concentrated mostly on the positive aspects of authority can be the nature of their work and the context, where social workers work, because the organization $\mathrm{X}$ is a non-governmental organization and the participation of children at the child day center is voluntary and not obligatory. Therefore, children and other service users might be less likely to perceive the authority of social workers as a forced institution and the relationship with service users becomes the main tool of effective work with them.

\section{Qualities needed to be Authority at a Day Care Center according to Practitioners}

After answering a general question, what is a social worker with authority is, the participants of a focus group discussed what qualities a social worker of a children day care center need to have or obtain in order to become a social worker with authority. Participants identified various qualities - both personal and professional qualities, some related to charisma and a character of a person working at a day care center, others to their expertise, knowledge and competences. It was observed during the discussion that practitioners having more experience were more proactive, 
defining the skills and qualities necessary for a social worker at a day care center. It might be related with their experience and increased confidence at work, better understanding of the role and its requirements, its power and limits, which are described in the document defining the general requirements of a children day care center and they might have internalized better the values of the specific organization. The qualities identified by practitioners are really diverse; however they can fall into several categories. One category to describe a social worker with authority identified by practitioners during focus group discussion is leadership. Practitioners identified that a social worker with authority should "set an example by his / her behavior", "can manage a group and make it interested in activities", "can lead a group". A. Skarbaliene (2015) made a comparison between the concept of leadership and authority and argued that these concepts have many similarities and sometimes leadership can go alongside authority. However, when defining authority, she puts a stronger emphasis on a relationship and a moral dimension as the necessary components of authority and argues that authority and leadership are not the same. The definitions of practitioners are also close to B.Bitinas (2004) definition of authority, who argues that authority can be linked with being an example for others.

The second category is ability of a social worker to build a positive relationship with service users and others. According to practitioners, a social worker needs to be "patient and understanding", "respect himself and boundaries", "respect others and is respected", "accepts other the way they are", "has a strong relationship with a child". As J. M. Bochenski (2004) participants emphasized not just the capacity of individuals but put a strong emphasis on the status of an individual, which derives from the relationship.

The third category could be reliability and professionalism of a social worker. According to practitioners "the words and actions of a social worker should match", he / she can "set and maintain clear boundaries till the end", "set an example by his/her behavior". The last category could be authenticity of a person, which includes various personal qualities and a charisma of a person such as "being yourself, sincere and self-confident", having "goals and vision, what people are and what is important to them", "has individuality, own views, opinion, feels valued", "respects himself and boundaries", "you can get new ideas from him", "loving his job". It seems that ability of a social worker to build positive relationships with service users and personal authenticity are the qualities, which are the most desired for a social worker with authority, because the biggest number of identified qualities could fall under these two categories. A new perspective, which was also presented by practitioners and not found in the analyzed theories that authority is closely related to self-perception, the relationship with themselves, self-confidence and self-respect of social workers and not only the relationship with others and 
their possessed skills and qualities. They expect social workers with authority to be "self-confident", suggest that he/she "feels valued", "respects himself and others". Therefore, self-confidence is also an important category to define authority. The picture below represents all these 5 categories, which were constructed from perceptions of research participants about a social worker with authority.

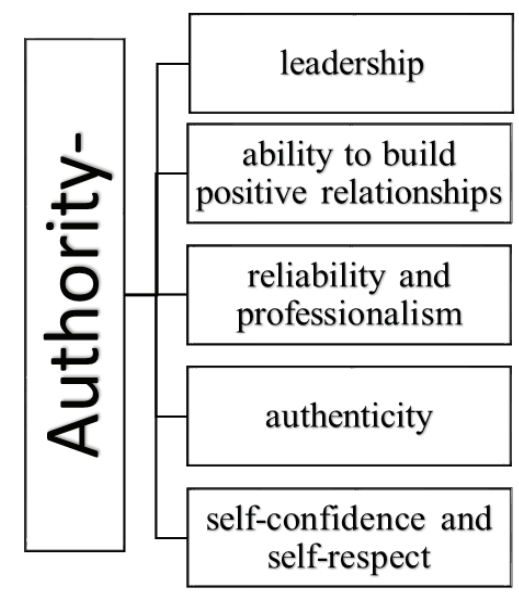

Fig. 2. The main concepts of authority constructed by the researcher from the responses of respondents

\section{The Ways to become a Social Worker with Authority according to Practitioners}

Practitioners identified various ways, how to become a practitioner with authority working at a day care center. 2 different positions were presented by practitioners. One that authority is something you can learn or gain over time if you gain necessary "competencies, knowledge, experience" and have the examples you can follow - can "learn from others, who are more experienced" and "being in a friendly professional relationship". This attitude is also emphasized in an analyzed document of the organization, which defines its values. Research participants identified similar ways of becoming authority as J. M. Bochenkski's (2004) description of epistemic authority. According to him, epistemic authority depends on professional training, skills and knowledge gained by specific training and skills, which are used in daily professional practice. Practitioners also identified that you "need cooperation, support and help at organization", need to have "a clear structure and clarity about your role", "to know the methods and principles of work, to be clear about your role". One practitioner added that you have "a strong supporting fam- 
ily" referring to relationships among colleagues, which need to be as strong as in a family to help for a social worker to maintain his / her authority. Therefore, it means that supporting relationships and support systems and authority examples within the organization are also important factors for creating and maintaining authority of social workers. It was also emphasized that it is important to have a clear structure and clarity about the role. The other position, which was presented by practitioners that a social worker "might be doomed to failure trying to become authority artificially" and it is important to "be yourself, honest, self-confident", "set and maintain clear boundaries", and know how to "keep your position". They put emphasis on authenticity of a social worker and his/her personal qualities. These positions are not contradictory but separate personal and professional dimensions of authority. According to most of practitioners, ideally, a social worker should have a combination of both - authentic personality and qualities related to gained experience and professional qualities. D. Hepworth et al. (2006) discuss about the importance of authenticity in direct social work practice.

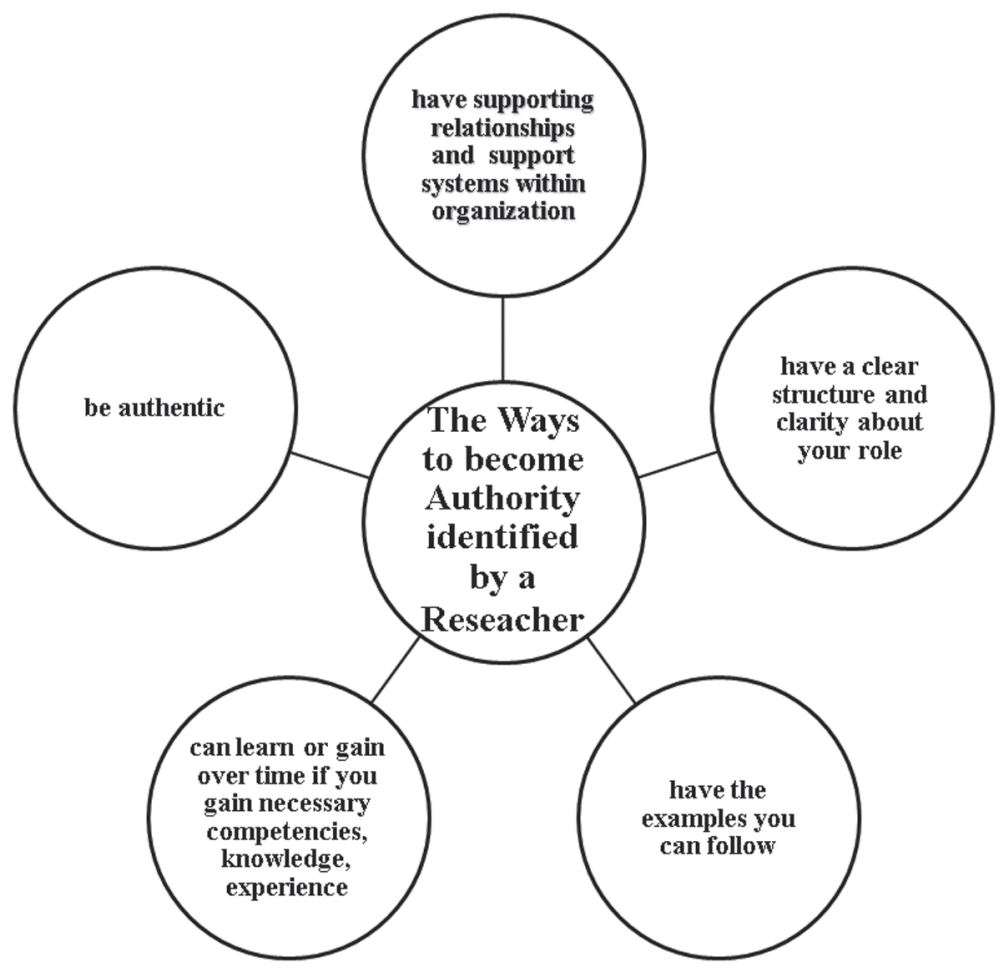

Fig. 3. The main categories of the ways to become authority identified by the researcher from the responses of respondents 
To sum up, the case study at a day care center revealed rich and diverse understanding, how practitioners and children perceive the authority of a social worker. Even though all research participants were practitioners at the same day care center and worked with the same group of children, their understanding and perceptions varied a lot depending on their experience at work, their values and personalities. Experienced workers were more confident to share their perceptions about the phenomena of authority and what it consists of, less experienced practitioners valued examples of authority, which they could follow and learn from.

\section{Conclusions}

The case study findings revealed that:

1. All focus group participants, when asked to define, how they understand, what the concept of authority means, identified the concept as being hard to define and measure and that it is not a common practice to think and evaluate their own authority to service users and get feedback of service users about that. A positive relationship was identified as the main component of authority of a social worker by most practitioners. Practitioners of the day center X especially emphasized the importance of having a positive relationship with children and their collegues to be authority at a day care center.

2. Practitioners identified dilemmas related to care and control functions related to authority of a social worker. Most of the concepts used by practitioners to describe authority were not instrumental and describe a moral dimension- such as a relationship with a child and approach, which includes respect, trust and love and willingness of a child to follow him/her, but some practitioners also warned of the dangers to become a forced institution and something that children might fear if authority of a social worker is not used well.

3. It important a holistic approach to the needs of social workers, because their authority was connected by not only to professional skills and competences such as leadership, reliability and professionalism, but also with their personality and authenticity, ability to build positive relationships, their self-confidence and self-respect. Practitioners also identified supporting relationships, support systems and authority examples within the organization, a clear structure and clarity about 


\title{
the role as important organizational factors for a social worker to be- come authority and be able to sustain it.
}

\author{
Received 20151223 \\ Approved for publishing 20160307
}

\section{References}

Banks, S. (2006). Ethics and Values in Social Work. Basingstoke: Palgrave Macmillan.

Bitinas, B. (2013). Rinktiniai edukologijos raštai, T. 3. Vilnius: Edukologija.

Bochenski, J. M. (2004). Kas yra autoritetas? Ivadas ị autoriteto logika. Vilnius: Mintis.

Bransford, C. (2005). Conceptions of authority within contemporary social work practice in managed mental health care organizations. Journal of Orthopsychiatry, Vol. 75(3), p. 409-420. Available at: http://www.ncbi. nlm.nih.gov/pubmed/16060736 [assessed on 10th of October, 2015].

Clark, C. (2006). Moral Character in Social Work. British Journal of Social Work, Vol. 36, p. 75-89.

Creswell, J. W. (2003). Research design Qualitative, Quantitative and Mixed Methods Approaches. 2nd ed. London: Sage Publications.

Hugman, R. (2005). New Approaches in Ethics fot the Caring Professions. Basingstoke: Palgrave.

Hepworth, D. et al. (2006). Direct social work practice: Theory and skills. 7th ed. Belmont, CA: Brooks Cole.

Gambrill, E. (2001). Social work: an Authority - Based Profession. Research on Social Work Practice, March, Vol. 11, No. 2, p. 166-175. Available at http://rsw.sagepub.com/content/11/2/166.full.pdf + html [accessed on 14th of September, 2015].

Lietuvos Respublikos socialinès apsaugos ir darbo ministerija. (2013). Vaiku dienos centru projektu vertinimo ir atrankos konkurso organizavimo nuostatai. Vilnius: Lietuvos Respublikos socialinès apsaugos ir darbo ministerija.

Lietuvos suaugusiųjų švietimo ir informavimo centras. (2007). Vaiku dienos centruose teikiamu socialiniu paslaugu ịvairovès ir kokybès, darbo su socialinès rizikos šeimomis ir vaikais veiksmingumo įvertinimas. Vilnius: Lietuvos švietimo ir informavimo centras.

Määttä, K., Uusiautti S. (2012). Pedagogical Authority and Pedagogical Love incompatible? International Journal of Whole Schooling, Vol. 8, No. 1.

Millar, M. (2008). Anti-Oppressiveness: Critical Comments on a Discourse and its Context. British Journal of Social Work, Vol. 38, p. 362-375.

Robinson, R. R. (2014). Understanding the Development of Legitimate Teacher Authority through the Teacher-Student Relationship. Norman: University of Oklahoma. Available at: https://shareok.org/bitstream/handle/11244/10349/000Robin\%20Roberson\%20PhD\%20Dissertation\%20Final.pdf?sequence= 2\&isAllowed $=y$ [accessed on 15 th of October, 2015].

Sipovič, I. (2007). Vaikų dienos centrų administravimo ir vertinimo problemiškumas. Viešoji politika ir administravimas, Nr. 22. Available at: https://www.mruni.eu/lt/mokslo_darbai/.../dwn.php [accessed on $25^{\text {th }}$ of September, 2015].

Skarbalienè, A. (2015). Leadership moral Authority and moral Values in postmodern context. Klaipèda: Klaipėdos universitetas.

Tijūnèlienè, O. (2006). Mokytojo autoriteto kaip pozityvaus ugdomojo veiksnio: teorija ir empirika. Klaipėda: Klaipèdos universitetas.

Oxford Dictionaries. "Authority". Available at: http://www.oxforddictionaries.com/words/about [accessed on 25, November 2014].

Yin, R. K. (2014). Case Study Research: Design and Methods. 5th ed. London: Sage Publications. 
